I.V. Krivtsun, I.V. Pentegov, V.M. Sydorets, S.V. Rymar

\title{
A TECHNIQUE FOR EXPERIMENTAL DATA PROCESSING AT MODELING THE DISPERSION OF THE BIOLOGICAL TISSUE IMPEDANCE USING THE FRICKE EQUIVALENT CIRCUIT
}

\begin{abstract}
Purpose. Modeling the dispersion of the biological tissue impedance of vegetable and animal origin using the Fricke equivalent circuit; development of a technique for experimental data processing to determine the approximation coefficients of the dispersion of the biological tissue impedance for this equivalent circuit; study of the features of the equivalent circuit at modeling the dispersion of the impedance, resistance, and reactance; the definition of the frequency domain in which using of the equivalent circuit is correct; revealing and generalization of the main regularities of dissipation of biological tissue impedance of vegetable and animal origin. Methodology. The technique is based on the scientific provisions of theoretical electrical engineering - the theory of the electromagnetic field in nonlinear media in modeling the dispersion of the biological tissue impedance. Results. The electric circuit of the Fricke equivalent circuit allows modeling the dependences of the impedance module of biological tissues, active and reactive components of impedance with acceptable accuracy for practical purposes in the frequency domain from $10^{3}$ to $10^{6} \mathrm{~Hz}$. The equation of impedance of the Fricke equivalent circuit for biological tissues makes it possible to approximate the frequency dependences of the impedance modulus, active and reactive parts of the total resistance only by using the approximation coefficients corresponding to each part. The developed method for determining the values of the approximation coefficients of the impedance equation for the Fricke equivalent circuit for biological tissues allows to determine these values with high accuracy for various biological tissues. It is shown that the frequency dependences of the active component of the total resistance for tissues of vegetable and animal origin are similar. Originality. The developed technique operates with the normalized values of the impedance modulus of the Fricke equivalent circuit, the active and reactive components of the impedance as a function of frequency, which allows a comparative analysis of the dependencies of these parameters of various biological tissues of plant and animal origin. Practical value. The approximate dependences of the absolute impedance modulus, active and reactive components of the impedance allow modeling processes occurring in biological tissues with the passage of a current of different frequency. Dependence of the impedance of biological tissue can be applied to the design of diagnostic and control equipment to determine the properties of tissues of animal and vegetable origin, including developing more effective medical equipment. References 15, tables 3, figures 16.
\end{abstract}

Key words: biological tissue, electrical properties, simulation, impedance dispersion, Fricke substitution scheme, technique, approximation coefficients.

Разработана методика обработки экспериментальных данных для определения коэффициентов аппроксимации импеданса биологических тканей растительного и животного происхождения при моделировании дисперсии импеданса с помощью схемы замещения Фрике. Проведен анализ свойств схемы замещения Фрике, ее возможностей и особенностей при моделировании дисперсии импеданса, резистанса и реактанса. Показано, что при нормировании дисперсии активные составляющие импеданса для тканей растительного и жсивотного происхождения подобны. Библ. 15 , табл. 3 , рис. 16 .

Ключевые слова: биологическая ткань, электрические свойства, моделирование, дисперсия импеданса, схема замещения Фрике, методика, коэффициенты аппроксимации.

Introduction. The dispersion, that is, the frequency dependence, of the impedance (total or complex resistance) and its components - resistance (active resistance) and reactance (reactive resistance) of biological tissues is important in the study of the effect of electric current on them. This applies to electrical safety, diagnosis and treatment of humans and animals, monitoring the quality of agricultural products. Now this issue has become very relevant in connection with the creation of special surgical equipment for welding live tissues by currents of high frequency [1].

The goal of the paper is simulation of dispersion of the impedance of biological tissues of plant and animal origin using the Fricke substitution scheme [2, 3]; creation of a technique for processing experimental data to determine the coefficients of approximation of the dispersion of the impedance of biological tissues for the Fricke substitution scheme; the study of the features of this substitution circuit in modeling the variance of impedance, resistances, and reactance; the determination of the frequency range in which the use of the replacement circuit is correct; identification and generalization of the main regularities of dispersion of the impedance of biological tissues of plant and animal origin.

The studies are based on experimental data from different authors. The examples of data processing presented in the article are presented in a form that is intended for use in the MathCAD package [4].

The results of solving this problem are relevant for specialists who create diagnostic and control instrumentation for determining the properties of tissues of animal and plant origin. Also they will be in demand when creating medical equipment for welding live tissues.

Structure of biological tissue. Biological tissue consists of cells and intercellular substance. The cells themselves are complex formations, consisting of many

(C) I.V. Krivtsun, I.V. Pentegov, V.M. Sydorets, S.V. Rymar 
elements found in a protein substance bounded by cellular membranes (see Fig. 1).

From the point of view of electrical engineering, we will be interested in the change in the impedance of biological tissue from the frequency while passing through it an alternating electric current (AC) which is supplied to the tissue by electrodes with area $S$ spaced from each other at a distance $l$.

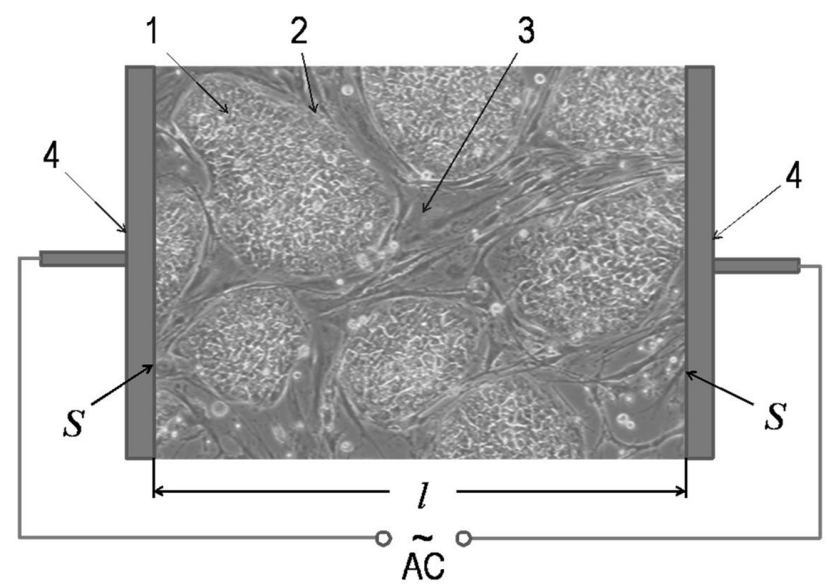

Fig. 1. The structure of a biological tissue consisting of cells 1 bounded by the cell membranes 2 and the intercellular substance 3 (when measuring the impedance, it is placed between the two electrodes 4)

The electromagnetic properties of biological tissues are determined by the characteristics of the organic material filled with electrolyte. In biological tissues, the electrolyte is an intercellular substance and cellular contents $[5,6]$. Due to the presence of membranes and films that have capacitance, cell resistance is mainly capacitive in nature.

When measuring the electrical parameters of biological tissues at the boundary between the measuring electrodes and the tissue (electrolyte) when an electric current passes, a double electric layer appears, also having a capacitive character. The double electric layer is approximately described by Stern adsorption theory [7]. The effect of the double electric layer is particularly pronounced with constant current and low frequencies. It is here that the greatest error is introduced into the measurement of the electrical parameters of biological tissues. With increasing frequency, the effect of the double electrical layer decreases.

To reduce the influence of the double electrical layer, when measuring the electrical parameters of biological tissues, as a rule, two pairs of electrodes are used. One pair is supplied with an electric current, and the measurements are made by another pair of electrodes [8].

Dielectric permeability of biological tissue. The permittivity $\underline{\varepsilon}[9,10]$ (here and below the underlining indicates the complex value) of the biological tissue contains the real $\varepsilon^{\prime}$ and the imaginary part $\varepsilon^{\prime \prime}$, both of which depend on the frequency $f: \underline{\varepsilon}(f)=\varepsilon^{\prime}(f)-j \cdot \varepsilon^{\prime \prime}(f)$, where $j=\sqrt{-1}$ is the imaginary unit. Fig. 2 shows a typical dependence of the dielectric permeability modulus $|\underline{\varepsilon}|$ of the biologic tissue (in this case, muscle $[3,5,6]$ ) of the frequency in the frequency range from $10^{1}$ до $10^{12} \mathrm{~Hz}$. Dependence has three characteristic areas $\alpha, \beta, \gamma$.

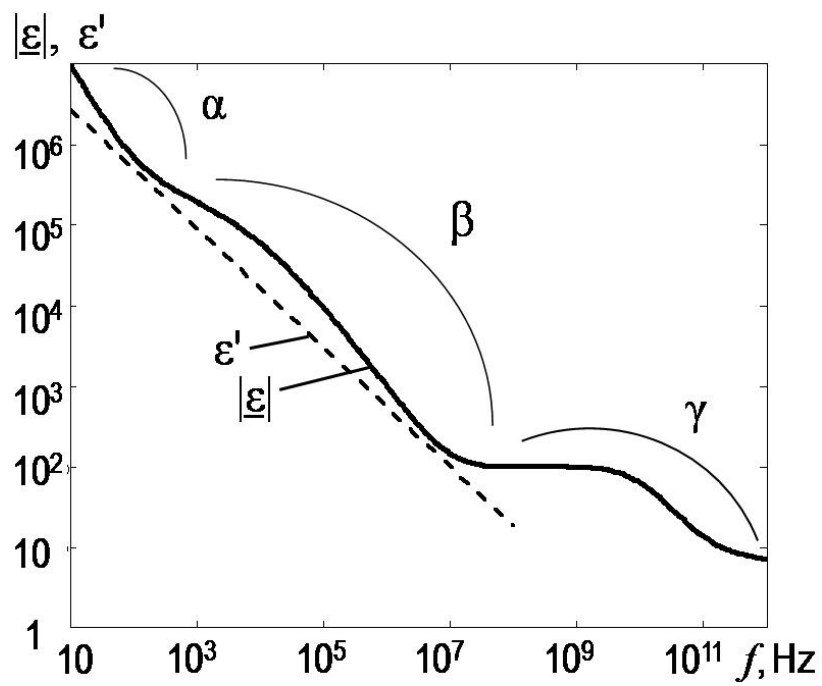

Fig. 2. Dependence of the dielectric permeability module $|\underline{\varepsilon}|$ of biological tissue $[3,5,6]$ and the largest calculated values of its real part $\varepsilon "$ on the frequency $f$

The presence of ranges of sites is due to $[5,6]$ :

- $\alpha:\left(f<10^{3} \mathrm{~Hz}\right)$ - the flow of current through the intercellular substance, when the resistance of cells for low-frequency current is still high and the dielectric constant is determined by the polarization of intracellular compartments and the inertia of the motion of molecules with a large molecular mass at resonance phenomena, and phenomena in a double electric layer;

- $\beta$ : $\left(10^{3} \Gamma ц<f<10^{8} \mathrm{~Hz}\right)$ - current flow through the intercellular substance, cellular membranes and cellular contents and reflects the relaxation polarization of polar macromolecules, and is determined by their effective radii and viscosity of the medium, as well as the dielectric losses in the cell membranes - tangent the dielectric loss angle $\operatorname{tg} \delta=\varepsilon^{\prime \prime} / \varepsilon^{\prime}$ serving as a quantitative measure of the relative contribution of the electrically conductive and dielectric properties of the medium when the electromagnetic field interacts with it $[5,10]$. Note that the values of $\operatorname{tg} \delta, \varepsilon^{\prime}$ и $\varepsilon^{\prime \prime}$ only partially simulate the reaction of the tissue to the passage of the electromagnetic field through it and do not reflect all the physical processes taking place in the tissue;

- $\gamma:\left(f>10^{8} \mathrm{~Hz}\right)$ - phenomena of resonance of water molecules of intercellular substance and cellular contents, and orientational polarization of water molecules.

The boundaries of the ranges $\alpha, \beta, \gamma$ and the values $|\underline{\varepsilon}|$ can differ from those shown in Fig. 2, depending on the type of biological tissue.

One of the methods of modeling in electrical engineering is the creation of electrical circuits of substitution [11]. In modeling the electrical processes in biological tissue, we will adhere to this method.

Fricke electrical circuit for the replacement of biological tissues. When modeling the dispersion of the impedance of biological tissues, the substitution scheme [2] (Fig. 3) proposed in the early 20 s of the 20 th century 
by the Danish-American physicist Hugo Fricke (18921972) is often used. The circuit simulates electrical processes in biological tissue at frequencies from $10^{1}$ до $10^{6} \mathrm{~Hz}$, that is, in sections $\alpha$ (with the exception of very low frequencies) and $\beta$.

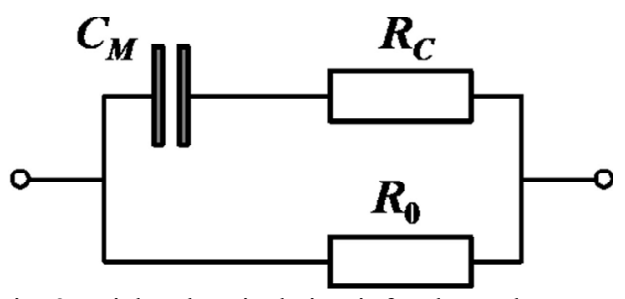

Fig. 3. Fricke electrical circuit for the replacement of biological tissue

The replacement circuit contains: $C_{M}-$ the frequency-dependent equivalent electrical capacitance of cell membranes; frequency independent equivalent active resistances (resistances) of cell contents $R_{C}$ and of intercellular substance $R_{0}$.

If we consider the resistivities and capacitances with dimensionality, respectively, $[\Omega \cdot \mathrm{m}]$ and $[\mathrm{F} / \mathrm{m}]$, then the elements of the substitution circuit in Fig. 3 should be considered as specific.

In the simplest case shown in Fig. 1, the relationship between the specific total electrical resistance and the total electrical resistance (impedances) has the form:

$$
\underline{Z}_{s}(f)=\underline{Z}(f) \cdot S / l
$$

the relationship between the active resistivities and the active electrical resistances:

$$
R_{s . C}(f)=R_{C} \cdot S / l ; R_{s .0}(f)=R_{0} \cdot S / l ;
$$

the equivalent specific electrical capacitance of cell membranes $C_{S . M}$ is determined from the expression:

$$
C_{s . M}(f)=C_{M}(f) \cdot l / S \text {. }
$$

The specific electric capacitances directly proportional to the product of the dielectric constant $\varepsilon_{0}=$ $8.854 \cdot 10^{-12} \mathrm{~F} / \mathrm{m}$ and the real part $\varepsilon^{\prime}$ of the complex relative dielectric permeability $\underline{\varepsilon}$ :

$$
C_{s . M}(f)=C_{M}(f) \cdot l / S=\varepsilon_{0} \cdot \varepsilon^{\prime}(f) .
$$

The total electrical resistance of the Fricke substitution scheme as a function of frequency is:

$$
\underline{Z}(f)=\frac{1}{\frac{1}{R_{0}}+\frac{1}{R_{C}+\frac{1}{j \cdot 2 \cdot \pi \cdot f \cdot C_{M}(f)}}} .
$$

Dividing the right and left parts of formula (1) by the resistance $R_{0}$, we obtain the expression for the impedance $\underline{Z} *(f)=\underline{Z}(f) / R_{0}$ of the substitution scheme in dimensionless form (the values denoted by the asterisk "*" are dimensionless) when normalized to unity [12 ] in the low-frequency range:

$$
\underline{Z}_{*}(f)=\frac{1}{1+\frac{1}{\frac{R_{c}}{R_{0}}+\frac{1}{j \cdot 2 \cdot \pi \cdot f \cdot C_{M}(f) \cdot R_{0}}}} .
$$

We introduce dimensionless coefficients $a_{1}, a_{2}$ and $a_{3}$ and a power function:

$$
\begin{gathered}
R_{0} / R_{C}=a_{1} ; \\
2 \cdot \pi \cdot f \cdot C_{M}(f) \cdot R_{0}=\frac{R_{0}}{X(f)}=\left(\frac{f}{f_{0}}\right)^{a_{2}} \cdot a_{3} .
\end{gathered}
$$

Here $X$ is the reactive resistance (reactance):

$$
X(f)=\left[2 \cdot \pi \cdot f \cdot C_{M}(f)\right]^{-1} ;
$$

$f_{0}$ is the base frequency, which can be assumed equal to 1 Hz. It is introduced because the exponentiation of a dimensional quantity $f$ in the irrational power of $a_{2}$ is not correct. We denote the ratio $f / f_{0}$ by the dimensionless quantity $f_{*}$.

As a result, we write the expression for the Fricke substitution circuit (1) normalized per unit impedance in the form of an approximation function:

$$
\underline{Z}_{*}\left(f_{*}, a_{1}, a_{2}, a_{3}\right)=\frac{1}{1+\frac{1}{\frac{1}{a_{1}}+\frac{1}{j \cdot f_{*}^{a_{2}} \cdot a_{3}}}} .
$$

With this form of writing, we obtain

$\underline{Z} *\left(0, a_{1}, a_{2}, a_{3}\right)=1 ; \underline{Z} *\left(\infty, a_{1}, a_{2}, a_{3}\right)=1 /\left(1+a_{1}\right)$ at any values of $a_{i}$, where $i$ is the index number at the coefficient $a, i=1,2,3$.

Approximate dimensionless coefficients $a_{1}, a_{2}$ and $a_{3}$ will be found from experimental data.

We have considered the case when in expressions (1) - (4) resistances have the dimension [ $\Omega]$, and the capacitances - [F]. If the experimental data are obtained for specific resistances and capacitances with dimension of $[\Omega \cdot \mathrm{m}]$ and $[\mathrm{F} / \mathrm{m}]$, then the elements of the substitution circuit in Fig. 3 will be specific.

In the analysis, the values can be applied either in $[\Omega]$ and $[\mathrm{F}]$, or in $[\Omega \cdot \mathrm{m}]$ and $[\mathrm{F} / \mathrm{m}]$, since using the specific values in expression (2) instead of absolute values, $l$ and $S$ are shortened, and the result remains the former.

When passing from dimensionless to dimension in expression (6), it is necessary to multiply $\underline{Z} *\left(f, a_{1}, a_{2}, a_{3}\right)$ by $R_{0}$ when calculating absolute resistances in [ $\Omega$ ], or by $R_{s .0}$ when calculating resistivities in $[\Omega \cdot \mathrm{m}]$. The values of $R_{0}$ and $R_{s .0}$ for obtaining the minimum error must be determined at frequency of up to $50 \mathrm{~Hz}$.

We explain the choice of the power function in expression (4) in determining the ratio of the quantities $R_{0} / X(f)$.

Since the complex dielectric permeability $\underline{\varepsilon}$ contains also the imaginary part $\varepsilon^{\prime \prime}$, its modulus is determined from the expression: $|\underline{\varepsilon}|=\sqrt{\left(\varepsilon^{\prime}\right)^{2}+\left(\varepsilon^{\prime \prime}\right)^{2}}$ from which it follows that the condition $\varepsilon^{\prime} \leq|\underline{\varepsilon}|$ is always satisfied. In this connection, the values of $\varepsilon^{\prime}(f)$ which can be determined by the power function $\left(f / f_{0}\right)^{a_{2}} \cdot a_{3}$ (in the logarithmic scale, it is the straight line $\varepsilon^{\prime}$ in Fig. 2), should lie below the values of the curve $|\underline{\varepsilon}|$. In this case, the expression (4) corresponds to a given power function.

Frequency dependences of the impedance of biological tissues. The publications $[6,13]$ contain information on the frequency dependences of the 
impedance module $\left|\underline{Z}_{s}\right|$ the active and reactive component of the impedance - the specific resistivity $R_{s}$ and the specific reactance $X_{s}$ of plant tissues - apple, carrot and potato in the frequency range from $25 \mathrm{~Hz}$ to $1 \mathrm{MHz}$. Frequency dependences of the active resistance $R$ of biological tissues of animal origin (rat) - liver, heart, kidney, breast and thyroid gland in the frequency range from $0.5 \ldots 1.5 \mathrm{kHz}$ to $1.0 \ldots 1.5 \mathrm{MHz}$ are given in [14 ].

Fig. 4 by points shows the experimental values of the electrical resistances of apple, carrot and potato on the frequency $[6,13]$, the lines show the approximations obtained with the lspline and interp functions of the MathCAD package, and Fig. 5 - experimental values of active electrical resistances on the frequency [14]: liver, heart (along the fibers), kidney, breast, thyroid gland.

Minimizing the root-mean-square deviations to find the values of the impedance approximation coefficients for the Fricke replacement circuit. To find the coefficients $a_{i}$, the approximation function of the impedance of the Fricke substitution circuit (6), we use the genfit function of the MathCAD package implementing the numerical Levenberg-Marquardt method [15]. For this function, a vector $V\left(f, a_{1}, a_{2}, a_{3}\right)$ is formed from equation (6) and the equations of its partial derivatives with respect to the required coefficients $a_{i}$.
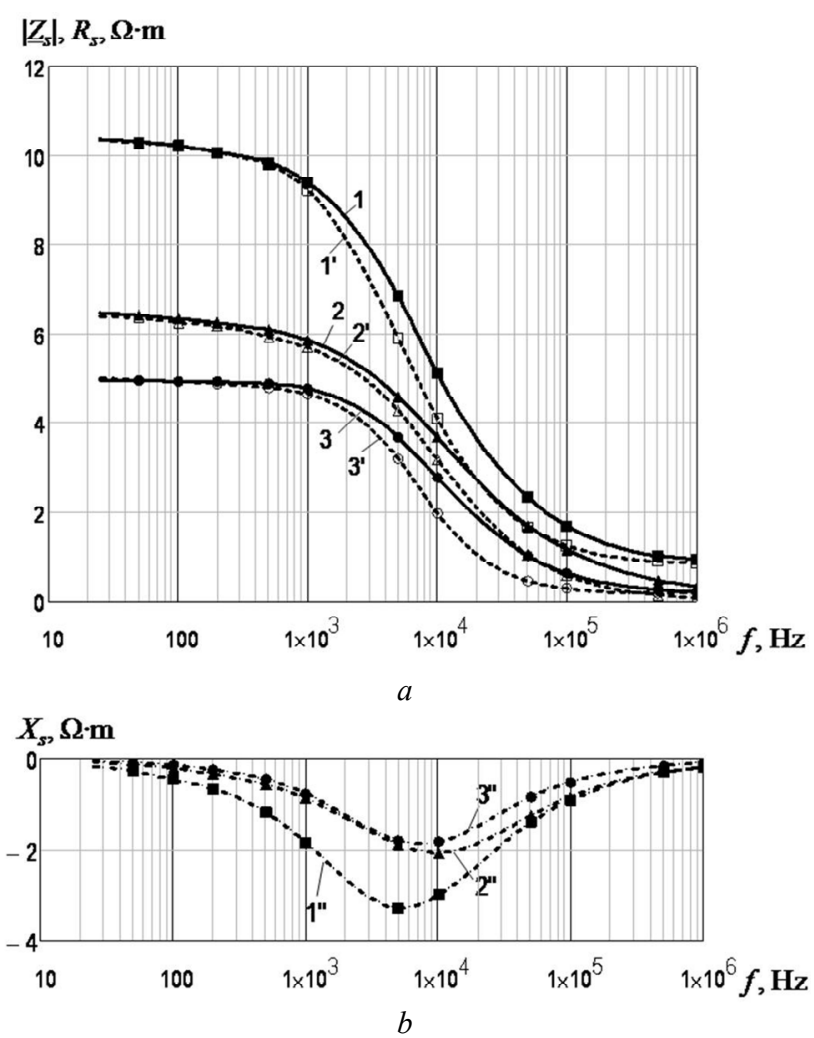

Fig. 4. Frequency dependences of experimental values of electrical resistances of biological tissues of plant origin $[6,13]$ : (a) - modulus of total resistivity $\left|\underline{Z}_{s}(f)\right|$ (digits without a stroke), active $R_{s}(f)$ (digits with a stroke) and $(b)$ - reactive $X_{s}(f)$ (digits with two strokes) - impedance components, respectively, for tissues: 1, 1', 1" - apple, 2, 2', 2" - carrots and 3, 3', 3" - potatoes

With the known experimental dependences of the resistances: $\left|\underline{Z}_{*}\right|=\left|\underline{Z}_{S}\right| / R_{s .0}$ or $|\underline{Z} *|=|\underline{Z}| / R_{0} ; R_{*}=R_{S} / R_{s .0}$ or
$R_{*}=R / R_{0} ; X_{*}=X_{S} / R_{s .0}$ or $X_{*}=X / R_{0}$ on the frequency $f$ for a biological tissue, for example for apple, carrot or potato (Fig. 4), it is possible to compose the vectors $V_{Z}, V_{R}$, or $V_{X}$, respectively, for the impedance modulus, active and reactive components of impedance, see Annex.

We define an arbitrary vector of values of the frequencies for valuation by unity

$$
f_{*_{n}}=10^{n}
$$

where $n$ is the index at the frequency $f_{*}$ which determines the ordinal number of the number in the vector $f_{*_{n}}$, for example, $n=1 . .6$ (note that the more terms in $n$, the more accurate the approximation dependence).

At given some initial values to the coefficients $a_{i}$, minimization using the function genfit, written as:

$$
\begin{aligned}
a_{Z, i} & =\operatorname{genfit}\left(f_{*},\left|\underline{Z}_{*}\right|, a_{1}, a_{2}, a_{3}, V_{Z}\right) ; \\
a_{R, i} & =\operatorname{genfit}\left(f_{*}, R_{*}, a_{1}, a_{2}, a_{3}, V_{R}\right) ; \\
a_{X, i} & =\operatorname{genfit}\left(f_{*}, X_{*}, a_{1}, a_{2}, a_{3}, V_{X}\right),
\end{aligned}
$$

occurs when determining the values of the coefficients $a_{Z, i}, a_{R, i}$ и $a_{X, i}$ which in the best way approximate the approximation curves

$$
\begin{gathered}
\left|\underline{Z} *\left(f_{*}\right)\right|=\left|\underline{Z} *\left(f_{*,} a_{Z, 1}, a_{Z, 2}, a_{Z, 3}\right)\right| ; \\
R_{*}\left(f_{*}\right)=\operatorname{Re}\left[\underline{Z}_{*}\left(f_{*}, a_{R, 1}, a_{R, 2}, a_{R, 3}\right)\right] ; \\
X_{*}\left(f_{*}\right)=\operatorname{Im}\left[\underline{Z} *\left(f_{*}, a_{X, 1}, a_{X, 2}, a_{X, 3}\right)\right]
\end{gathered}
$$

(using formula (6)) to the corresponding experimental values normalized to unity.

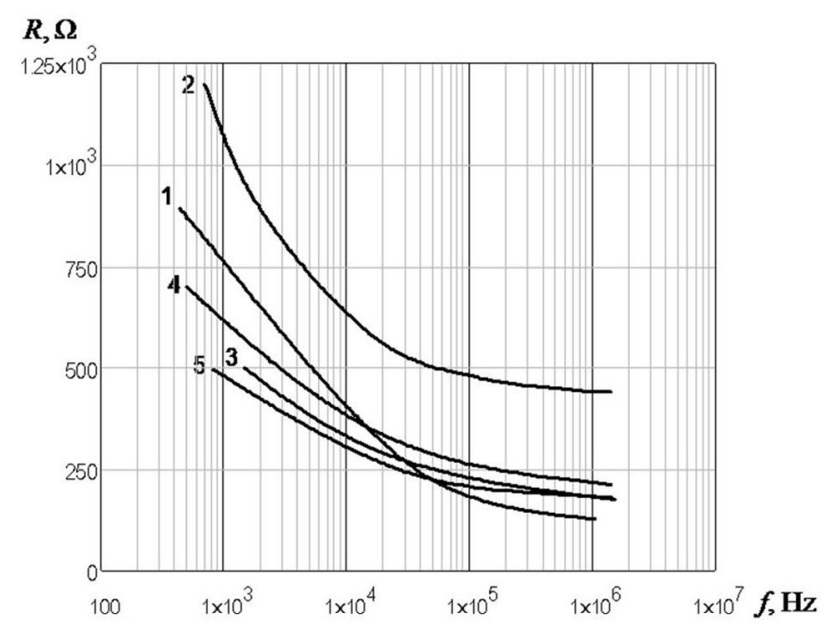

Fig. 5. Frequency dependences of experimental values of active electrical resistances $R(f)$ of biological tissues of animal origin

(rat) [14]: 1 - liver; 2 - hearts (along the fibers); 3 - kidney; 4 - the breast; 5 - thyroid gland

For biological tissues of plant origin - apples, carrots and potatoes $[6,13]$ in Fig. 6,8 , and 10, the experimental and calculated values of the frequency dependences of the impedance modulus $\left|\underline{Z} *\left(f_{*}\right)\right|$ of the Fricke replacement circuit, the active $R_{*}\left(f_{*}\right)$ and the reactive $X_{*}\left(f_{*}\right)$ impedance components are presented. For biological tissues of animal origin - liver, heart, kidney, breast and thyroid gland [14] in Fig. 12 the frequency dependences of the values of the active components $R *\left(f_{*}\right)$ of the impedance of the Fricke substitution scheme are plotted for tissues: 1 - liver; 2 - heart (along the fibers); 3 - the kidney; 4 - breast; 5 - thyroid gland. 


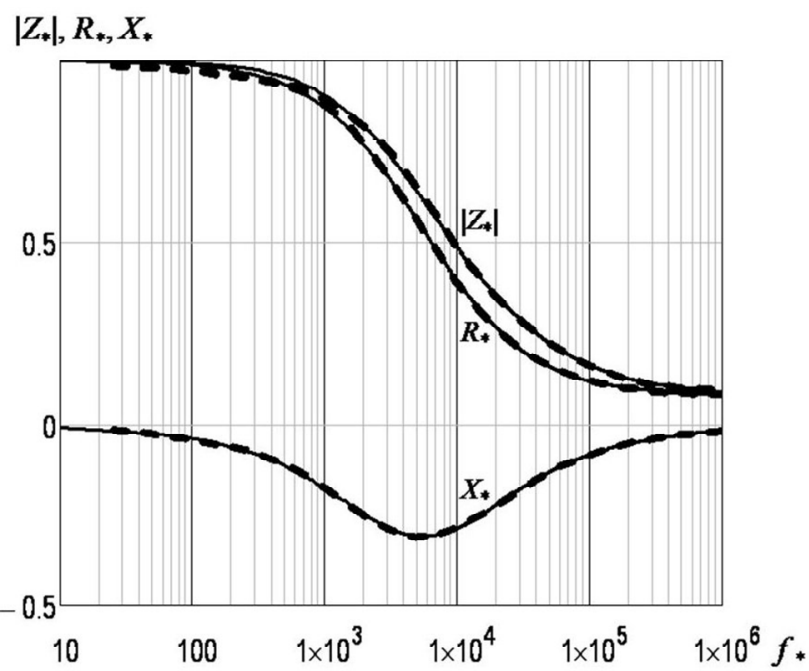

Fig. 6. The frequency dependences of the impedance modulus $\left|\underline{Z} *\left(f_{*}\right)\right|$ of the Fricke substitution scheme, the active $R_{*}\left(f_{*}\right)$ and the reactive $X_{*}\left(f_{*}\right)$ impedance components for the apple tissue. Thickened dashed curves - experimental values $[6,13]$, thin solid curves - calculated values

From the consideration of the graphs it can be seen that the calculated curves along their entire length coincide with the experimental values.

In Fig. 7, 9 and 11 graphs are presented of the frequency dependences of the relative deviations $\Delta_{Z}, \Delta_{R}$ and $\Delta_{X}[\%]$ of the calculated values of the quantities $\underline{Z_{*}}\left(f_{*}\right) \mid, \quad R_{*}\left(f_{*}\right)$ and $X_{*}\left(f_{*}\right), \quad$ respectively, on their experimental values for tissues of plant origin, and in Fig. 13 graphs of frequency dependences of relative deviations $\Delta_{R}[\%]$ of calculated values of $R_{*}\left(f_{*}\right)$ from their experimental values for tissues of animal origin.

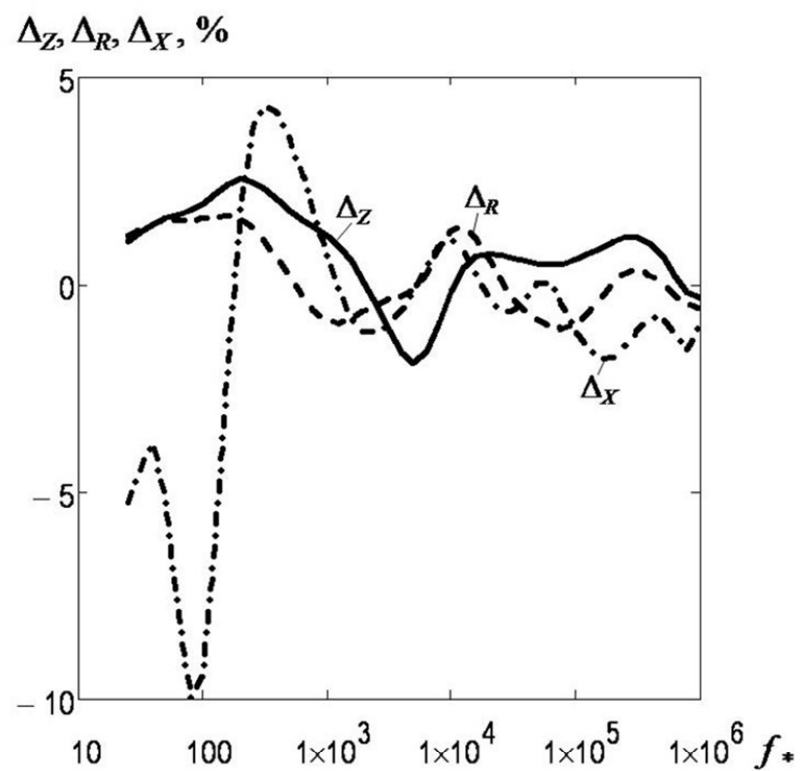

Fig. 7. Frequency dependences of relative deviations $\Delta_{Z}, \Delta_{R}$ and $\Delta_{X}$ of the calculated values of the quantities, respectively, $\left|\underline{Z} *\left(f_{*}\right)\right|, R_{*}\left(f_{*}\right)$ and $X_{*}\left(f_{*}\right)$ from their experimental values for the apple tissue

In the frequency range widely used in the analysis of the impedance of biological tissues [3] in the range $f=10^{3} \ldots 10^{6} \mathrm{~Hz}$ for apple, the deviations $|\Delta|$ do not exceed $1.9 \%$, for carrots $2.3 \%$, for potatoes $-2.5 \%$, for the liver $3.0 \%$, for the heart $1.8 \%$, for the kidney $-2.0 \%$, for the breast $1.0 \%$, for thyroid gland $1.5 \%$. This is an acceptable for practical purposes coincidence of calculated values with experimental data in the specified frequency range.

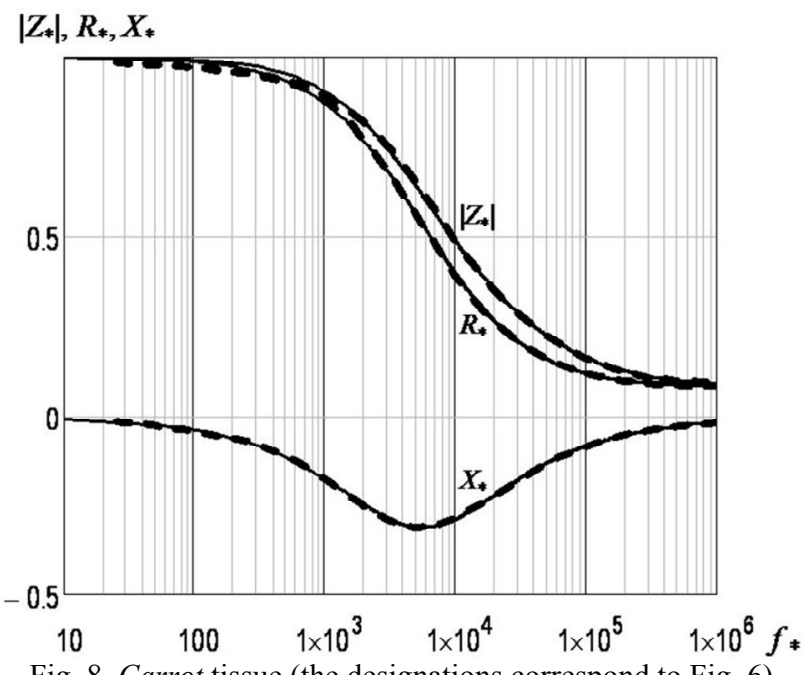

Fig. 8. Carrot tissue (the designations correspond to Fig. 6)

Table 1 shows the values of the coefficients $a_{i}$ and the largest deviation $|\Delta|$ of the calculated values of $\left|\underline{Z}_{*}\right|, R_{*}$ and $X_{*}$ from their experimental values in the frequency range $f_{*}=10^{3} \ldots 10^{6}$ for biological tissues of plant origin: apple, carrot and potato, and Table 2 presents the values of the coefficients $a_{i}$ and the largest deviation $|\Delta|$ of the calculated values of $R_{*}$ from their experimental values for biological tissues of animal origin: liver, heart (along the fibers), kidney, breast and thyroid gland. Table 3 shows the calculated values of $R_{s .0}$ and $R_{0}$ for various biological tissues of plant and animal origin.

For tissues of plant origin, the estimated values of $R_{s .0}$ were roughly determined from the graphs in Fig. 4, $a$ by interpolating the experimental $R_{s}(f)$ curves from $25 \mathrm{~Hz}$ to small frequency values.

With the $R_{s .0}$ values obtained, the approximation curves $\left|\underline{Z} *\left(f_{*}\right)\right|, R_{*}\left(f_{*}\right)$ and $X_{*}\left(f_{*}\right)$ have a small deviation from the experimental curves. Although it should be understood here that the $R_{s .0}$ values obtained for tissues of plant origin may deviate somewhat from the real values of $R_{s .0}$ at a low frequency because of the effect of the double electrical layer in the near-electrode regions. It is also possible to change the resistance of cell membranes with a close arrangement of cells and the difficult passage of current through the intercellular substance because of the presence of small conductors of small bridges between the cell membranes that touch each other. This issue requires further research.

When choosing the calculated values of $R_{0}$ of biological tissues of animal origin, difficulties arose because the experimental values of the curves in Fig. 5 were presented with minimum frequencies of $0.5 \ldots 1.5$ $\mathrm{kHz}$, and it was not possible to correctly interpolate the dependences of $R(f)$ on the ordinate axis to determine $R$ 


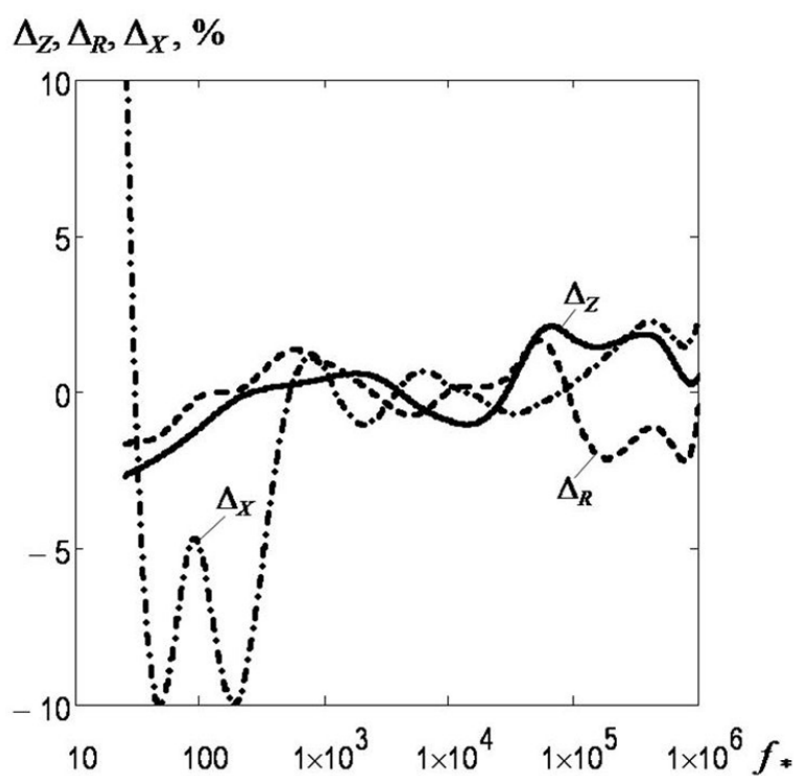

Fig. 9. Carrot tissue (the designations correspond to Fig. 7)

$\left|Z_{*}\right|, R_{*}, X_{*}$

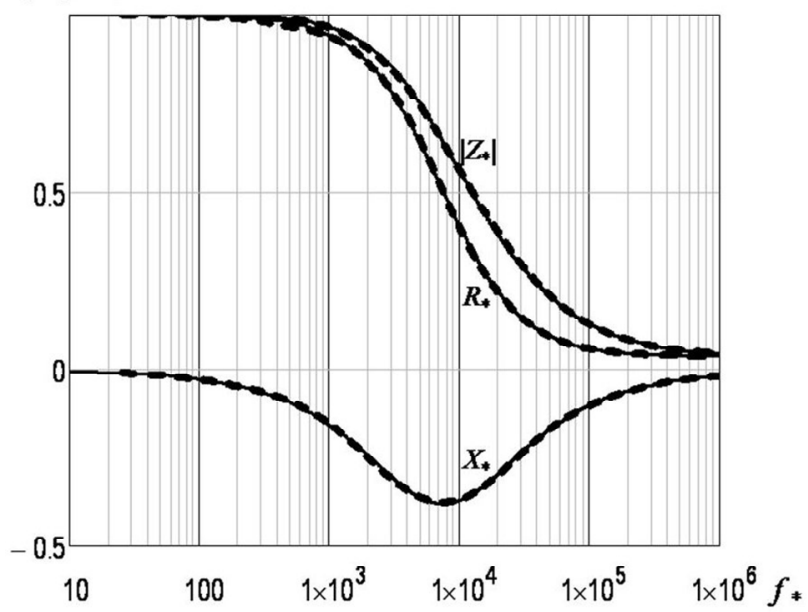

Fig. 10. Potato tissue (the designations correspond to Fig. 6)

\section{$\Delta_{Z}, \Delta_{R}, \Delta_{X}, \%$}

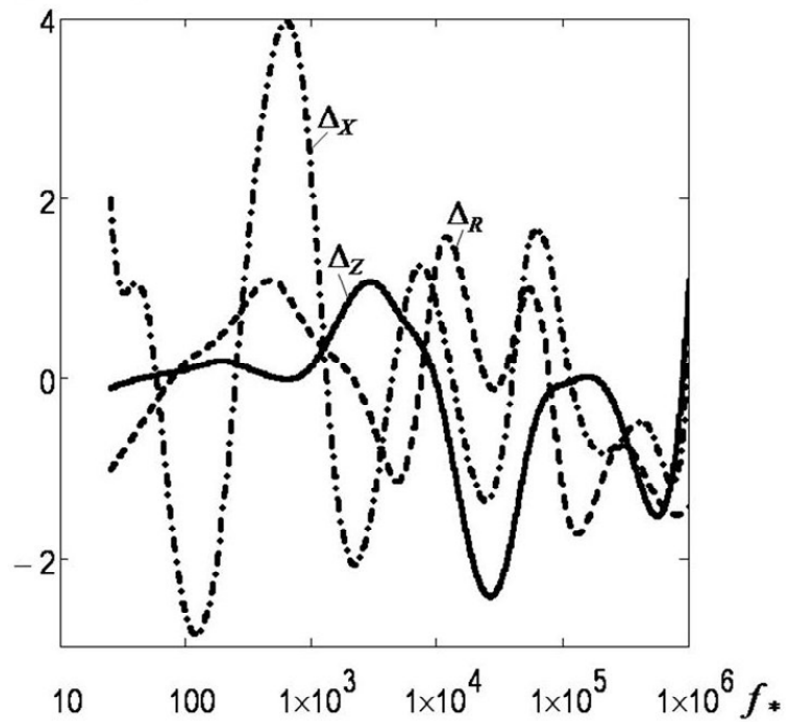

Fig. 11. Potato tissue (the designations correspond to Fig. 7) values at low frequencies. Therefore, the calculated values of $R_{0}$ are taken very approximately and such that the approximation curves $R *(f)$ coincide with the experimental curves in the entire range of available experimental data. Thus, the calculated values of $R_{0}$ of tissues of animal origin in Table 3 may differ from the actual values. But in determining the values of $R(f)$ in the frequency range $10^{3} \ldots 10^{6} \mathrm{~Hz}$ from the approximate dependences $R_{*}(f)$ obtained, taking into account the values of $R_{0}$, the result obtained coincides with the data in Fig. 4, which is proved by the obtained dependences of $\Delta_{R}$ in Fig. 13.

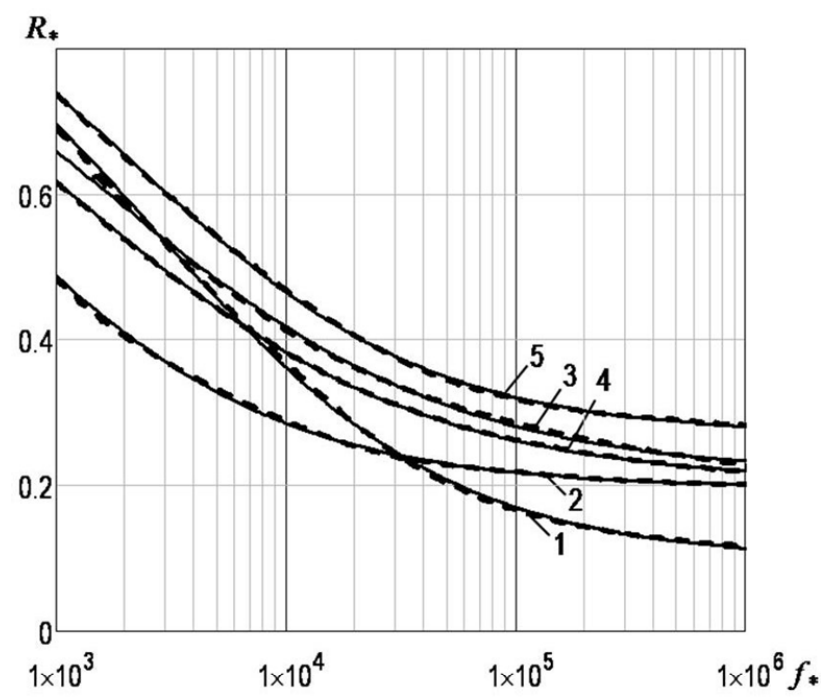

Fig. 12. Frequency dependences of the active components $R_{*}\left(f_{*}\right)$ values of impedance $\underline{Z} *\left(f_{*}\right)$ of the Fricke substitution scheme for tissues: 1 - liver; 2 - heart (along the fibers); 3 - kidney;

4 - breast; 5 - thyroid gland. Thickened dashed curves experimental values [14], thin solid curves - calculated values

$\Lambda_{R}, \%$

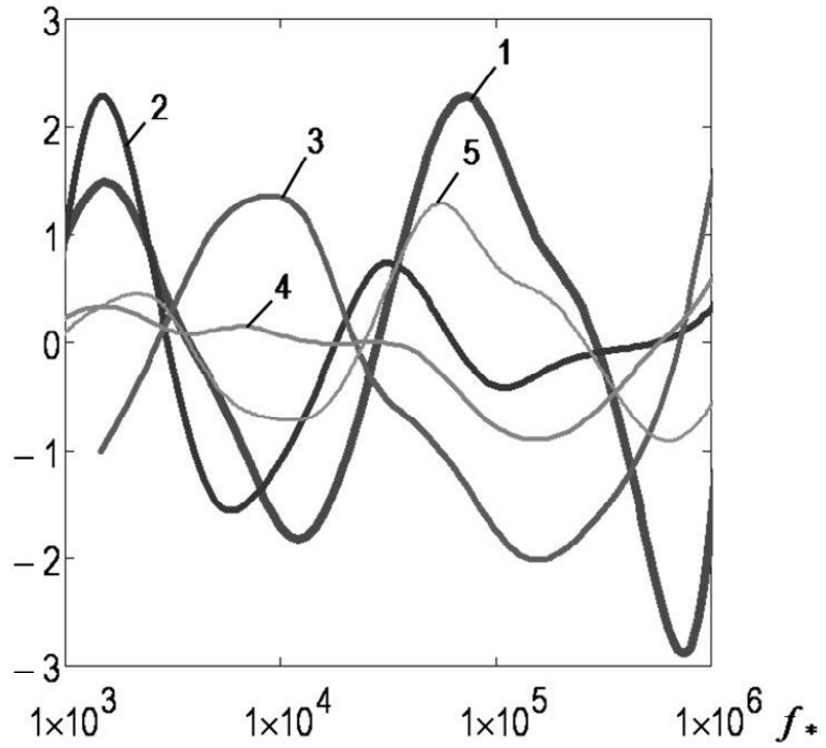

Fig. 13. Frequency dependences of relative deviations $\Delta_{R}$ of calculated values of $R_{*}\left(f_{*}\right)$ values from their experimental values for tissues: 1 - liver; 2 - heart (along the fibers); 3 - kidney; 4 - breast; 5 - thyroid gland 
Table 1

The coefficients $a_{i}$ and the largest deviation $|\Delta|$ of the calculated values of $\mid \underline{Z} *, R_{*}$ and $X *$ from their experimental values in the frequency range $f_{*}=10^{3} \ldots 10^{6}$ for various biological tissues of plant origin

\begin{tabular}{|l|c|c|c|c|}
\hline \multicolumn{5}{|c|}{ Coefficients for $|\underline{Z} *|$} \\
\hline \multicolumn{1}{|c|}{ Tissue } & $a_{Z, 1}$ & $a_{Z, 2}$ & $a_{Z, 3}$ & $|\Delta|, \%$ \\
\hline Apple & 11.2 & 0.588 & $7.413 \cdot 10^{-3}$ & 1.9 \\
\hline Carrot & 444.0 & 0.570 & $7.395 \cdot 10^{-3}$ & 2.1 \\
\hline Potato & 26.2 & 0.740 & $1.556 \cdot 10^{-3}$ & 2.5 \\
\hline \multicolumn{5}{|c|}{ Coefficients for $R_{*}$} \\
\hline \multicolumn{7}{|c|}{ Tissue } & $a_{R, 1}$ & $a_{R, 2}$ & $a_{R, 3}$ & $|\Delta|, \%$ \\
\hline Apple & 11.7 & 0.536 & $9.131 \cdot 10^{-3}$ & 1.4 \\
\hline Carrot & 443.3 & 0.506 & $9.369 \cdot 10^{-3}$ & 2.2 \\
\hline Potato & 28.1 & 0.710 & $1.775 \cdot 10^{-3}$ & 1.7 \\
\hline \multicolumn{5}{|c|}{ Coefficients for $X_{*}$} \\
\hline Tissue & $a_{X, 1}$ & $a_{X, 2}$ & $a_{X, 3}$ & $|\Delta|, \%$ \\
\hline Apple & 1.646 & 0.681 & $1.748 \cdot 10^{-3}$ & 1.6 \\
\hline Carrot & 1.911 & 0.665 & $1.476 \cdot 10^{-3}$ & 2.3 \\
\hline Potato & 3.200 & 0.760 & $8.684 \cdot 10^{-3}$ & 2.2 \\
\hline
\end{tabular}

Table 2

The coefficients $a_{i}$ and the largest deviation $\Delta$ of the calculated values of $R_{*}$ from their experimental values in the frequency range $R_{*}$ for various biological tissues of animal origin

\begin{tabular}{|l|c|c|c|c|}
\hline \multicolumn{5}{|c|}{ Coefficients for $R_{*}$} \\
\hline \multicolumn{1}{|c|}{ Tissue } & $a_{R, 1}$ & $a_{R, 2}$ & $a_{R, 3}$ & $|\Delta|, \%$ \\
\hline Liver & 9.265 & 0.339 & 0.062 & 3.0 \\
\hline Heart & 4.084 & 0.330 & 0.109 & 1.8 \\
\hline Kidney & 3.679 & 0.286 & 0.095 & 2.0 \\
\hline Breast & 3.899 & 0.285 & 0.107 & 1.0 \\
\hline $\begin{array}{l}\text { Thyroid } \\
\text { gland }\end{array}$ & 2.701 & 0.344 & 0.051 & 1.5 \\
\hline
\end{tabular}

Table 3

The calculated values of $R_{0}$ and $R_{s .0}$ for various biological

tissues of plant and animal origin
\begin{tabular}{|l|c|}
\hline \multicolumn{2}{|c|}{ Tissue } \\
\hline \multicolumn{2}{|c|}{$R_{s .0}, \Omega \cdot \mathrm{m}$} \\
\hline Apple & 10.50 \\
\hline Carrot & 6.30 \\
\hline Potato & 4.95 \\
\hline \multicolumn{2}{|c|}{$R_{0}, \Omega$} \\
\hline Liver & 1100 \\
\hline Heart & 2200 \\
\hline Kidney & 800 \\
\hline Breast & 1000 \\
\hline Thyroid gland & 650 \\
\hline
\end{tabular}

After finding the unknown variables $a_{i}, a_{R, i}$ da $a_{X, i}$ it is possible to determine the values of the total resistivity of the Fricke replacement circuit, the active and reactive components of the total resistivity in absolute values as a function of frequency:

$$
\begin{gathered}
\left|\underline{Z}_{s}(f)\right|=R_{s .0} \cdot\left|\underline{Z}_{*}\left(f_{*,} a_{Z, 1}, a_{Z, 2}, a_{Z, 3}\right)\right| ; \\
R_{s}(f)=R_{s .0} \cdot \operatorname{Re}\left[\underline{Z} *\left(f_{*}, a_{R, 1}, a_{R, 2}, a_{R, 3}\right)\right] ; \\
X_{s}(f)=R_{s .0} \cdot \operatorname{Im}\left[\underline{Z} *\left(f_{*}, a_{X, 1}, a_{X, 2}, a_{X, 3}\right)\right],
\end{gathered}
$$

and for tissues of animal origin - the active component of the impedance:

$$
R(f)=R_{0} \cdot \operatorname{Re}\left[\underline{Z} *\left(f_{*,} a_{R, 1}, a_{R, 2}, a_{R, 3}\right)\right] .
$$

Having pairs of dependences of the quantities $\left|\underline{Z} *\left(f_{*}\right)\right|, R *\left(f_{*}\right)$ or $X_{*}\left(f_{*}\right.$ we can determine the third value by the formulas:

$$
\begin{gathered}
\left|\underline{Z}_{*}\left(f_{*}\right)\right|=\left\{\left[R_{*}\left(f_{*}, a_{R, 1}, a_{R, 2}, a_{R, 3}\right)\right]^{2}+\right. \\
\left.+\left[X_{*}\left(f_{*}, a_{X, 1}, a_{X, 2}, a_{X, 3}\right)\right]^{2}\right\}^{\frac{1}{2}} \\
R_{*}\left(f_{*}\right)=\left\{\left|\underline{Z}_{*}\left(f_{*}, a_{Z, 1}, a_{Z, 2}, a_{Z, 3}\right)\right|^{2}-\right. \\
\left.-\left[X_{*}\left(f_{*}, a_{X, 1}, a_{X, 2}, a_{X, 3}\right)\right]^{2}\right\}^{\frac{1}{2}} \\
X_{*}\left(f_{*}\right)=\left\{\left|\underline{Z}_{*}\left(f_{*}, a_{Z, 1}, a_{Z, 2}, a_{Z, 3}\right)\right|^{2}-\right. \\
\left.-\left[R_{*}\left(f_{*}, a_{X, 1}, a_{X, 2}, a_{X, 3}\right)\right]^{2}\right\}^{\frac{1}{2}} .
\end{gathered}
$$

In Fig. 14, the approximation dependences of the active components $R_{*}$ of the total impedances of the Fricke substitution scheme for biological tissues $[6,13]$ of plant and the animal [14] origin on the frequency $f_{*}$ are jointly presented at unitized values. It can be seen that the behavior of the curves for tissues of plant and animal origin is similar.

Using the approximation coefficients $a_{Z, i}, a_{R, i}$ or $a_{X, i}$ in the impedance expression for the Fricke replacement circuit for all the dependences $\left|\underline{Z} *\left(f_{*}\right)\right|$, $\boldsymbol{R} *\left(\boldsymbol{f}_{*}\right)$ and $\boldsymbol{X} *\left(\boldsymbol{f}_{*}\right)$. We show that using the approximation coefficients $a_{Z, i}$ to construct the curves $R_{*}\left(f_{*}\right)$ и $X_{*}\left(f_{*}\right)$, as well as the coefficients $a_{R, i}$ for constructing the curves $\left|\underline{Z} *\left(f_{*}\right)\right|$ and $X *\left(f_{*}\right)$, and the coefficients $a_{X, i}$ for the construction of the curves $\left|\underline{Z} *\left(f_{*}\right)\right|$ and $R *\left(f_{*}\right)$ does not lead to coincidence of calculated and experimental data. We show this by the example of the approximation coefficients $a_{Z, i}, a_{R, i}$ and $a_{X, i}$ for apple.

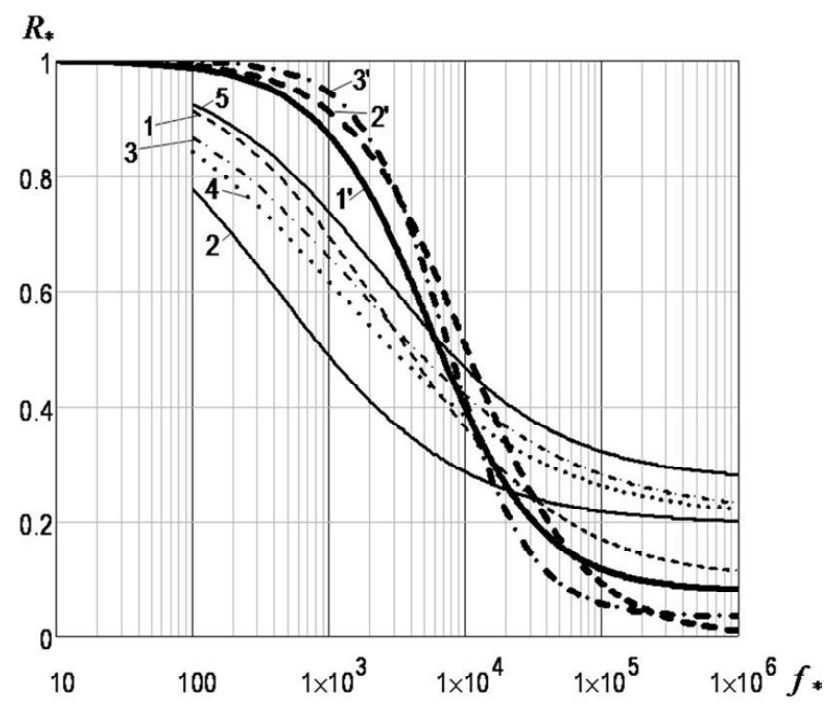

Fig. 14. The normalized per unit approximated frequency dependences of the values of the active components $R *\left(f_{*}\right)$ of the impedance of the Fricke substitution scheme for biological tissues of plant $[6,13]$ and the animal [14] origin: 1 - liver; 2 - heart (along the fibers); 3 - kidney; 4 - breast; 5 - thyroid gland; 1' - apple; 2'- carrots; 3' - potatoes 
We use the formula (6). We take the values of $a_{Z, i}$ from Table 1 for the apple. In Fig. 15 by thin solid lines we build dependencies

$$
\begin{gathered}
\left|\underline{Z}_{Z^{*}}\left(f_{*}\right)\right|=\left|\underline{Z} *\left(f_{*}, a_{Z, 1}, a_{Z, 2}, a_{Z, 3}\right)\right| ; \\
R_{Z^{*}}\left(f_{*}\right)=\operatorname{Re}\left[\underline{Z} *\left(f_{*}, a_{Z, 1}, a_{Z, 2}, a_{Z, 3}\right)\right] ; \\
X_{Z^{*}}\left(f_{*}\right)=\operatorname{Im}\left[\underline{Z}_{*}\left(f_{*}, a_{Z, 1}, a_{Z, 2}, a_{Z, 3}\right)\right],
\end{gathered}
$$

and by thickened dashed lines - their experimental values $\left|\underline{Z} *\left(f_{*}\right)\right|, R *\left(f_{*}\right)$ and $X_{*}\left(f_{*}\right)$. Let's see how the obtained curves are correlated with the experimental data.

It can be seen that the curves $\left|\underline{Z}_{Z^{*}}\left(f_{*}\right)\right|$ and $\left|\underline{Z_{*}}\left(f_{*}\right)\right|$ practically coincided, since the approximation coefficients $a_{Z, i}$ were calculated precisely from the experimental values of this curve. The curves of the dependence $R_{Z^{*}}\left(f_{*}\right)$ fall below the experimental values $R *\left(f_{*}\right)$, as well as the curves of the dependencies $X_{Z^{*}}\left(f_{*}\right)$ of the experimental values $X *\left(f_{*}\right)$.

Now take the values of $a_{R, i}$ for the apple and also substitute them in the formula (6). In Fig. 15 by thin dotted lines we construct the dependencies:

$$
\begin{gathered}
\left|\underline{Z}_{R^{*}}\left(f_{*}\right)\right|=\left|\underline{Z} *\left(f_{*}, a_{R, 1}, a_{R, 2}, a_{R, 3}\right)\right| ; \\
R_{R^{*}}\left(f_{*}\right)=\operatorname{Re}\left[\underline{Z} *\left(f_{*}, a_{R, 1}, a_{R, 2}, a_{R, 3}\right)\right] ; \\
X_{R^{*}}\left(f_{*}\right)=\operatorname{Im}\left[\underline{Z} *\left(f_{*}, a_{R, 1}, a_{R, 2}, a_{R, 3}\right)\right] .
\end{gathered}
$$

In this case, the curve $R_{R^{*}}\left(f_{*}\right)$ coincided with the curve $R *\left(f_{*}\right)$, the curve $\left|\underline{Z}_{R *}\left(f_{*}\right)\right|$ passed above the curve with the experimental values of $\left|\underline{Z} *\left(f_{*}\right)\right|$, and the curve $X_{R^{*}}\left(f_{*}\right)$ passed below the curve with the experimental values of $X_{*}\left(f_{*}\right)$.

If we take the values of $a_{X, i}$ for the apple, then in Fig. 15 by thin dot-dash lines we can build dependencies

$$
\begin{gathered}
\left|\underline{Z}_{X^{*}}\left(f_{*}\right)\right|=\left|\underline{Z}_{*}\left(f_{*}, a_{X, 1}, a_{X, 2}, a_{X, 3}\right)\right| ; \\
R_{X^{*}}\left(f_{*}\right)=\operatorname{Re}\left[\underline{Z}_{*}\left(f_{*}, a_{X, 1}, a_{X, 2}, a_{X, 3}\right)\right] ; \\
X_{X^{*}}\left(f_{*}\right)=\operatorname{Im}\left[\underline{Z}_{*}\left(f_{*}, a_{X, 1}, a_{X, 2}, a_{X, 3}\right)\right] .
\end{gathered}
$$

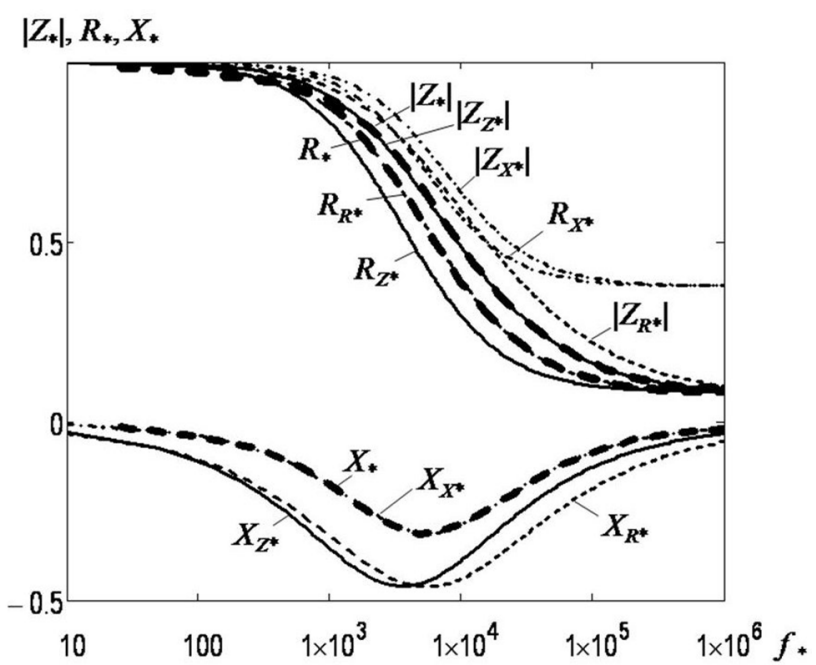

Fig. 15. The frequency dependences of the impedance modulus $\underline{Z} \underline{Z}_{*} \mid$ of the Fricke substitution scheme, the active $R *$ and the reactive $X_{*}$ impedance components for the apple tissue.

Thickened dashed curves are the experimental values of $\left|\underline{Z}_{*}\right|, R_{*}$ and $X_{*}$; thin solid curves - calculated values for the coefficients $a_{R, i}$ - the curves $\mid \underline{Z}_{Z^{*}}, R_{Z^{*}}$ and $X_{Z^{*}}$; fine dotted curves - calculated values for the coefficients $a_{R, i}$ - curves $\left|\underline{Z}_{R^{*}}\right|, R_{R^{*}}$ and $X_{R^{*}}$; thin dash-dotted curves - calculated values for the coefficients $a_{X, i}$ - the curves $\left|\underline{Z}_{X^{*}}\right|, R_{X^{*}}$ and $X_{X^{*}}$
The curve $X_{X^{*}}\left(f_{*}\right)$ coincided with the curve $X_{*}\left(f_{*}\right)$, the curves $\left|\underline{Z}_{X^{*}}\left(f_{*}\right)\right|$ and $R_{X^{*}}\left(f_{*}\right)$, especially at high frequencies, have significantly exceeded the corresponding curves of the experimental values $\left|\underline{Z} *\left(f_{*}\right)\right|$ and $R *\left(f_{*}\right)$.

Thus, the coefficients $a_{Z, i}, a_{R, i}$ and $a_{X, i}$ can be used only to approximate the corresponding curves $\left|\underline{Z} *\left(f_{*}\right)\right|$, $R *\left(f_{*}\right)$ и $X *\left(f_{*}\right)$ by the values of which they were obtained and for which the calculated curves coincide with the experimental curves.

Hence, having the values of the approximation coefficients $a_{R, i}$ in the impedance expression of the Fricke substitution circuit (6) for the experimental dependences

$$
R_{*}\left(f_{*}\right)=\operatorname{Re}\left[\underline{Z} *\left(f_{*}, a_{R, 1}, a_{R, 2}, a_{R, 3}\right)\right]
$$

of tissues of animal nature [14], see Table 2, it is impossible to obtain dependencies

$$
\begin{gathered}
\left|\underline{Z} *\left(f_{*}\right)\right|=\left|\underline{Z} *\left(f_{*}, a_{R, 1}, a_{R, 2}, a_{R, 3}\right)\right| ; \\
X *\left(f_{*}\right)=\operatorname{Im}\left[\underline{Z} *\left(f_{*}, a_{R, 1}, a_{R, 2}, a_{R, 3}\right)\right] .
\end{gathered}
$$

This is the main drawback of the Fricke substitution scheme.

Finding the common coefficients $a_{i}$ in the impedance expression of the Fricke replacement circuit for all the dependences $|\underline{Z} *(f *)|, R *(f *)$ and $X *(f *)$. Let us verify the possibility of finding the coefficients ai in the expression for the total complex resistance (6) of the Fricke substitution circuit, which simultaneously satisfy all the dependences $\left|\underline{Z} *\left(f_{*}\right)\right|, R_{*}\left(f_{*}\right)$ and $X *\left(f_{*}\right)$ for each particular tissue. In this case, by one dependence $\left|\underline{Z} *\left(f_{*}\right)\right|=\left|\underline{Z} *\left(f_{*}, a_{1}, a_{2}, a_{3}\right)\right|$ it would be possible to obtain the dependences $\quad R_{*}\left(f_{*}\right)=\operatorname{Re}\left[\underline{Z} *\left(f_{*}, a_{1}, a_{2}, a_{3}\right)\right] \quad$ and $X *\left(f_{*}\right)=\operatorname{Im}\left[\underline{Z}_{*}\left(f_{*}, a_{1}, a_{2}, a_{3}\right)\right]$. To do this, we use the minimization of the root-mean-square deviations of the function $F\left(a_{1}, a_{2}, a_{3}\right)$ written as:

$$
\begin{gathered}
F\left(a_{1}, a_{2}, a_{3}\right)= \\
=\sum_{n}\left\{\left|\underline{Z}_{*}\left(f_{*_{n}}, a_{1}, a_{2}, a_{3}\right)\right|-\left|\underline{Z}_{*}\left(f_{*_{n}}, a_{Z, 1}, a_{Z, 2}, a_{Z, 3}\right)\right|\right\}^{2}+ \\
+\sum_{n}\left\{\operatorname{Re}\left[\underline{Z}_{*}\left(f_{*_{n}}, a_{1}, a_{2}, a_{3}\right)\right]-\right. \\
\left.-\operatorname{Re}\left[\underline{Z}_{*}\left(f_{*_{n}}, a_{R, 1}, a_{R, 2}, a_{R, 3}\right)\right]\right\}^{2}+ \\
+\sum_{n}\left\{\operatorname{Im}\left[\underline{Z}_{*}\left(f_{*_{n}}, a_{1}, a_{2}, a_{3}\right)\right]-\right. \\
\left.-\operatorname{Im}\left[\underline{Z}_{*}\left(f_{*_{n}}, a_{X, 1}, a_{X, 2}, a_{X, 3}\right)\right]\right\}^{2},
\end{gathered}
$$

here the values of the vector $f_{*_{n}}$ are given from the expression (7), and the values $a_{Z, i}, a_{R, i}, a_{X, i}$ - from Table 1 .

Minimization of the function $F\left(a_{i}\right) \rightarrow$ min can be performed by the numerical method of conjugate gradients [15] with respect to the variables $a_{i}$ (in the MathCAD package is the Minimize function) for some initial values of the variables $a_{i}$.

As an example, let's take an apple. As a result of minimization, the following coefficients were obtained: $a_{1}$ $=6.91 ; a_{2}=0.784 ; a_{3}=1.144 \cdot 10^{-3}$. Based on these coefficients in Fig. 16 we build by solid curves for the curves of the calculated dependences of the quantities

$$
\begin{gathered}
\left|\underline{Z} *\left(f_{*}\right)\right|=\left|\underline{Z} *\left(f_{*}, a_{1}, a_{2}, a_{3}\right)\right| ; \\
R_{*}\left(f_{*}\right)=\operatorname{Re}\left[\underline{Z} *\left(f_{*}, a_{1}, a_{2}, a_{3}\right)\right] ; \\
X *\left(f_{*}\right)=\operatorname{Im}\left[\underline{Z} *\left(f_{*}, a_{1}, a_{2}, a_{3}\right)\right] .
\end{gathered}
$$




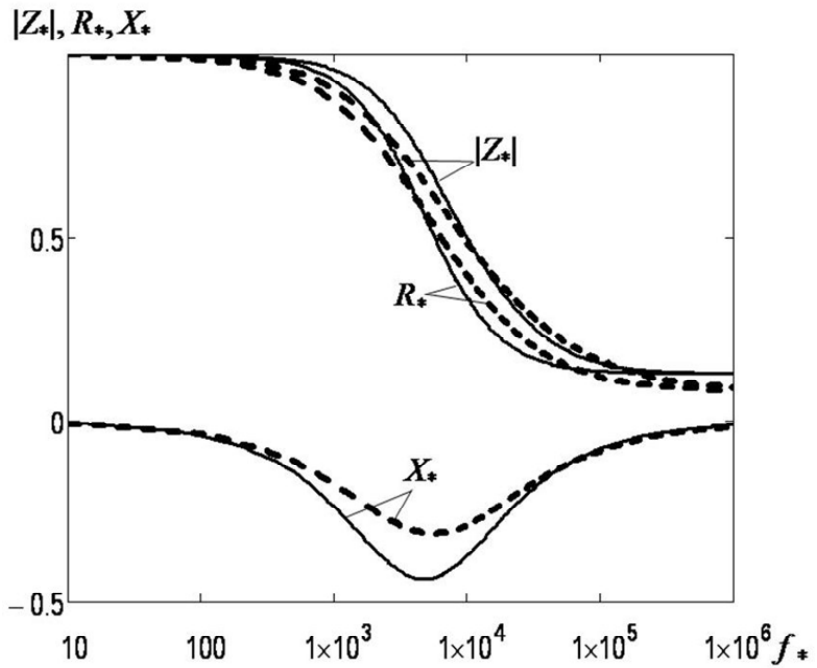

Fig. 16. The frequency dependences of the impedance modulus $|\underline{Z} *|$ of the Fricke substitution scheme, the active $R *$ and the reactive $X *$ impedance components for the apple tissue. Dotted curves - experimental values, solid curves - calculated values

It can be seen that all these curves diverge from the corresponding experimental curves shown in the figure by dashed lines.

This shows that for the Fricke substitution scheme there are no common values of the approximation coefficients $a_{i}$ that would simultaneously satisfy all the curves $\left|\underline{Z} *\left(f_{*}\right)\right|, R_{*}\left(f_{*}\right)=\operatorname{Re}\left[\underline{Z} *\left(f_{*}\right)\right]$ and $X_{*}\left(f_{*}\right)=\operatorname{Im}\left[Z_{*}\left(f_{*}\right)\right]$ for each specific biological tissue.

Therefore, to approximate the curves $\left|\underline{Z} *\left(f_{*}\right)\right|$, $\operatorname{Re}\left[\underline{Z} *\left(f_{*}\right)\right]$ and $\operatorname{Im}\left[\underline{Z} *\left(f_{*}\right)\right]$, only the corresponding coefficients $a_{Z, i}, a_{R, i}$ и $a_{X, i}$, at which the values of calculated and experimental data coincide, should be used. This is a consequence of the fact that the Fricke scheme does not reflect all the properties of biological tissues.

Therefore, the next stage of research should be devoted to the modernization of the Fricke substitution scheme with the introduction of elements in the scheme that take into account the effect of cell membranes and dielectric losses in cell membranes (the dielectric loss tangent $\operatorname{tg} \delta$ ) in order to obtain common values of the approximation coefficients $a_{i}$ that would simultaneously satisfy all the curves $\left|\underline{Z}_{*}\left(f_{*}\right)\right|, R_{*}\left(f_{*}\right)$ and $X_{*}\left(f_{*}\right)$ for each specific biological tissue.

The developed technique allows modeling processes occurring in biological tissues when currents of different frequency pass through them, and also with greater efficiency to develop diagnostic and control equipment for determining the electrical properties of tissues of plant and living origin, including developing more efficient medical equipment. Dependencies of $R *\left(f_{*}\right)$ can be applied in calculations of thermal processes occurring when welding live tissues of animal origin with special medical welding power sources.

Annex. The $V_{Z}, V_{R}$, and $V_{X}$ vectors for the impedance, active and reactive impedance components are:

$$
\begin{gathered}
V_{Z}\left(f_{*}, a_{1}, a_{2}, a_{3}\right)= \\
=|| \underline{Z_{*}}\left(f_{*}, a_{1}, a_{2}, a_{3}\right)|,| \frac{\partial \underline{Z}_{*}\left(f_{*}, a_{1}, a_{2}, a_{3}\right)}{\partial a_{1}} \mid, \\
=\| \operatorname{Re}\left[\underline{Z}_{*}\left(f_{*}, a_{1}, a_{2}, a_{3}\right)\right], \operatorname{Re}\left[\frac{\partial \underline{Z}_{*}\left(f_{*}, a_{1}, a_{2}, a_{3}\right)}{\left.\partial a_{2}, a_{3}\right)}|,| \frac{\partial \underline{Z}_{*}\left(f_{*}, a_{1}, a_{2}, a_{3}\right)}{\partial a_{3}}||^{T} ;\right. \\
V_{R}\left(f_{*}, a_{1}, a_{2}, a_{3}\right)= \\
\operatorname{Re}\left[\frac{\partial \underline{Z}_{*}\left(f_{*}, a_{1}, a_{2}, a_{3}\right)}{\partial a_{2}}\right], \operatorname{Re}\left[\frac{\partial \underline{Z}_{*}\left(f_{*}, a_{1}, a_{2}, a_{3}\right)}{\partial a_{3}}\right] \|^{T} ; \\
=\| \operatorname{Im}\left[\underline{Z}_{*}\left(f_{*}, a_{1}, a_{2}, a_{3}\right)\right], \operatorname{Im}\left[\frac{\partial \underline{Z}_{*}\left(f_{*}, a_{1}, a_{2}, a_{3}\right)}{\partial a_{1}}\right], \\
\operatorname{Im}\left[\frac{\partial \underline{Z}_{*}\left(f_{*}, a_{1}, a_{2}, a_{3}\right)}{\partial a_{2}}\right], \operatorname{Im}\left[\frac{\partial \underline{Z}_{*}\left(f_{*}, a_{1}, a_{2}, a_{3}\right)}{\partial a_{3}}\right] \|^{T},
\end{gathered}
$$

here $\partial$ is the differential sign; $T$ is the vector transpose symbol.

Transforming the right-hand sides of the vectors, taking into account formula (6), we obtain expressions for determining the coefficients $a_{i}$ in terms of the vectors $V_{Z}$, $V_{R}$, and $V_{X}$ written in explicit form:

$$
\begin{aligned}
& V_{Z}\left(f_{*}, a_{1}, a_{2}, a_{3}\right)= \\
& =\frac{\| \sqrt{\left[a_{1}^{2}+\left(1+a_{1}\right) \cdot\left(a_{3} \cdot f_{*}^{a_{2}}\right)^{2}\right]^{2}+\left(a_{1}^{2} \cdot a_{3} \cdot f_{*}^{a_{2}}\right)^{2}}}{F\left(f_{*}, a_{1}, a_{2}, a_{3}\right)}, \\
& -\frac{\left\{\begin{array}{l}
\left(1+3 \cdot a_{1}+3 \cdot a_{1}^{2}+a_{1}^{3}\right) \cdot\left(a_{3} \cdot f_{*}^{a_{2}}\right)^{4}- \\
-a_{1}^{3} \cdot\left[\left(1+a_{1}\right) \cdot\left(a_{3} \cdot f_{*}^{a_{2}}\right)^{2}-a_{1}\right]
\end{array}\right\} \cdot\left(a_{3} \cdot f_{*}^{a_{2}}\right)^{2}}{F_{1}^{2}\left(f_{*}, a_{1}, a_{2}, a_{3}\right) \cdot \sqrt{F_{2}\left(f_{*}, a_{1}, a_{2}, a_{3}\right)}}, \\
& -\frac{\left(2+a_{1}\right) \cdot a_{1}^{3} \cdot\left(a_{3} \cdot f_{*}^{a_{2}}\right)^{2} \cdot \ln \left(f_{*}\right)}{F_{1}^{2}\left(f_{*}, a_{1}, a_{2}, a_{3}\right) \cdot \sqrt{F_{2}\left(f_{*}, a_{1}, a_{2}, a_{3}\right)}}, \\
& -\frac{\left(2+a_{1}\right) \cdot a_{1}^{3} \cdot a_{3} \cdot f_{*}^{2 \cdot a_{2}}}{F_{1}^{2}\left(f_{*}, a_{1}, a_{2}, a_{3}\right)} \|^{T} \\
& V_{R}\left(f_{*}, a_{1}, a_{2}, a_{3}\right)=\| \frac{a_{1}^{2}+\left(1+a_{1}\right) \cdot\left(a_{3} \cdot f_{*}^{a_{2}}\right)^{2}}{F_{1}\left(f_{*}, a_{1}, a_{2}, a_{3}\right)}, \\
& -\frac{\left\{\left[\left(1+a_{1}\right) \cdot a_{3} \cdot f_{*}^{a_{2}}\right]^{2}-a_{1}^{2}\right\} \cdot\left(a_{3} \cdot f_{*}^{a_{2}}\right)^{2}}{F_{1}^{2}\left(f_{*}, a_{1}, a_{2}, a_{3}\right)}, \\
& -\frac{2 \cdot\left(1+a_{1}\right) \cdot a_{1}^{3} \cdot\left(a_{3} \cdot f_{*}^{a_{2}}\right)^{2} \cdot \ln \left(f_{*}\right)}{F_{1}^{2}\left(f_{*}, a_{1}, a_{2}, a_{3}\right)},
\end{aligned}
$$




$$
\begin{gathered}
-\frac{2 \cdot\left(1+a_{1}\right) \cdot a_{1}^{3} \cdot a_{3} \cdot f_{*}^{2 \cdot a_{2}}}{F_{1}^{2}\left(f_{*}, a_{1}, a_{2}, a_{3}\right)} \|^{T} ; \\
V_{X}\left(f_{*}, a_{1}, a_{2}, a_{3}\right)=\|-\frac{a_{1}^{2} \cdot a_{3} \cdot f_{*}^{a_{2}}}{F_{1}\left(f_{*}, a_{1}, a_{2}, a_{3}\right)}, \\
-\frac{2 \cdot a_{1} \cdot\left(1+a_{1}\right) \cdot\left(a_{3} \cdot f_{*}^{a_{2}}\right)^{3}}{F_{1}^{2}\left(f_{*}, a_{1}, a_{2}, a_{3}\right)}, \\
-\frac{a_{1}^{2} \cdot a_{3} \cdot f_{*}^{a_{2}} \cdot\left\{a_{1}^{2}-\left[\left(1+a_{1}\right) \cdot a_{3} \cdot f_{*}^{a_{2}}\right]^{2}\right\} \cdot \ln \left(f_{*}\right)}{F_{1}^{2}\left(f_{*}, a_{1}, a_{2}, a_{3}\right)}, \\
-\frac{a_{1}^{2} \cdot f_{*}^{a_{2}} \cdot\left\{a_{1}^{2}-\left[\left(1+a_{1}\right) \cdot a_{3} \cdot f_{*}^{a_{2}}\right]^{2}\right\}}{F_{1}^{2}\left(f_{*}, a_{1}, a_{2}, a_{3}\right)} \|^{T},
\end{gathered}
$$

where functions

$$
\begin{gathered}
F_{1}\left(f_{*}, a_{1}, a_{2}, a_{3}\right)=a_{1}^{2}+\left[\left(1+a_{1}\right) \cdot a_{3} \cdot f_{*}^{a_{2}}\right]^{2} ; \\
F_{2}\left(f_{*}, a_{1}, a_{2}, a_{3}\right)=\left[a_{1}^{2}+\left(1+a_{1}\right) \cdot\left(a_{3} \cdot f_{*}^{a_{2}}\right)^{2}\right]^{2}+ \\
+\left(a_{1}^{2} \cdot a_{3} \cdot f_{*}^{a_{2}}\right)^{2} .
\end{gathered}
$$

In some cases, expressions written in explicit form are more convenient to use.

\section{Conclusions.}

The electric substitution Fricke circuit makes it possible to model the dependences of the impedance module of biological tissues, the active and reactive components of the impedance with acceptable accuracy for practical purposes in the frequency range from $10^{3}$ up to $10^{6} \mathrm{~Hz}$.

The expression of the impedance of the Fricke substitution scheme for biological tissues makes it possible to approximate the frequency dependences of the impedance modulus, the active and reactive components of the impedance only by using the approximation coefficients corresponding to each component.

The developed technique for processing experimental data in modeling the dispersion of the impedance of biological tissues using the Fricke substitution scheme for biological tissues allows these values to be determined with high accuracy.

The developed technique operates with normalized to unity values of the impedance modulus of the Fricke substitution circuit, the active and reactive components of the impedance depending on the frequency, which makes it possible to perform a comparative analysis of the parameters of various biological tissues of plant and animal origin.

It is shown that the frequency dependences of the active component of the total resistance for tissues of plant and animal origin are similar.

The approximation coefficients in the impedance equation can only be used to approximate the impedance, resistance and reactance curves corresponding to them by the values of which they were obtained which is the main drawback of the Fricke substitution scheme.
For the Fricke substitution scheme, there are no common values of the approximation coefficients which would correspond simultaneously to three dependences the impedance module, the active and reactive component of the impedance. Therefore, the Fricke substitution scheme does not fully reflect all the characteristics of biological tissues and needs modernization.

Dependencies of the impedance of biological tissue can be used in the design of diagnostic, measuring and control equipment to determine the properties of tissues of animal and plant origin. Also they will be in demand when creating medical equipment for welding live tissues.

\section{REFERENCES}

1. Paton B.E., Krivtsun I.V., Marinsky G.S., Khudetsky I.Yu., Lankin Yu.N., Chernets A.V. Welding, cutting and heat treatment of live tissues. The Paton welding journal, 2013, no.10-11, pp. 142-153.

2. Fricke H. The electric resistance and capacity of blood for frequencies between 800 and $4 \frac{1}{2}$ million cycles. The Journal of General Physiology, 1925, vol.9, no.2, pp. 153-167. doi: 10.1085/jgp.9.2.153.

3. Kalakutskii L.I., Akulov S.A., Fedotov A.A. Fundamentals of impulse impedance of biological tissues: an electronic textbook. Minoboronauki Russia, Samara State Aerospace University named after S.P. Korolev (National Research University). Samara, 2011. 94 p. Available at: http://repo.ssau.ru/handle/Uchebnye-posobiya/ Osnovyimpulsnoi-impedansometrii-biologicheskih-tkanei-Elektronnyiresurs-elektron-ucheb-posobie-54991. (Rus).

4. Kiryanov D.V. MathCAD 14 [MathCAD 14]. St. Petersburg, BHV-Petersburg Publ., 2007. 704 p. (Rus).

5. Samoilov V.O. Meditsinskaia biofizika: Uchebnik [Medical Biophysics: Textbook]. St. Petersburg, SpetsLit Publ., 2004. 496 p. (Rus).

6. Golev I.M., Korotkov L.N. Dispersion of the electrical resistance of biological objects plant origin. Bulletin of Voronezh State Technical University, 2013, vol.9, no.4, pp. 2629. (Rus).

7. Antropov E.I. Teoreticheskaia elektrokhimiia. Uchebnik dlia khimiko-tekhnologicheskikh spetsial'nostei vuzov [Theoretical electrochemistry. Textbook for high schools chemical technology specialties]. Moscow, Vysshaia shkola Publ., 1975. 560 p. (Rus).

8. Laufer S., Ivorra A., Reuter V.E., Rubinsky B., Solomon S.B. Electrical impedance characterization of normal and cancerous human hepatic tissue. Physiological Measurement, 2010, vol.31, iss.7, pp. 995-1009. - doi: 10.1088/0967$3334 / 31 / 7 / 009$.

9. Neiman L.R., Demirchian K.S. Teoreticheskie osnovy elektrotekhniki. V 2 T., T.2, Ch. 3, 4. Teoriia nelineinykh elektricheskikh i magnitnykh tsepei. Teoriia elektromagnitnogo polia [Theoretical foundations of electrical engineering. In 2 vols. Vol. 2, part 3, 4. Theory of nonlinear electric and magnetic circuits. Theory of electromagnetic field]. Moscow-Leningrad, Energiia Publ., 1966. 407 p. (Rus).

10. Privalov E.E. Elektrotekhnicheskoe materialovedenie: uchebnoe posobie [Electrotechnical materials science: Tutorial]. Moscow-Berlin: Direkt-Media Publ., 2015. 234 p. (Rus).

11. Bessonov L.A. Teoreticheskie osnovy elektrotekhniki [Theoretical foundations of electrical engineering]. Moscow, Vysshaia shkola Publ., 1964. 750 p. (Rus).

12. Tolstov Iu.G. Teoriia lineinykh elektricheskikh tsepei [Theory of linear electric circuits]. Moscow, Vysshaia shkola Publ., 1978. 279 p. (Rus). 
13. Golev I.M., Bobkina E.Iu. The temperature dependence of the electrical impedance of the parenchymal tissue of vegetables. Teoreticheskie i prakticheskie aspekty estestvennykh i matematicheskikh nauk: Materialy mezhdunarodnoi zaochnoi nauchno-prakticheskoi konferentsii [Theoretical and practical aspects of the natural and mathematical sciences: Proceedings of the International correspondence scientific-practical conference]. Novosibirsk, 24 December 2012, SibAK Publ., 2012, pp. 103-108. (Rus). Available at: http://sibac.info/conf/ naturscience/i/30882. (Rus).

14. Belik D.V. Impedansnaia elektrokhirurgiia [Impedance electrosurgery]. Novosibirsk, Nauka Publ., 2000. 237 p. (Rus). 15. Gill Ph., Murray W., Wright M. Prakticheskaia optimizatsiia [Practical Optimization]. Moscow, Mir Publ., 1985. 509 p. (Rus).
I.V. Krivtsun ${ }^{1}$, Academician of the National Academy of Science of Ukraine, Doctor of Technical Science, Professor,

I.V. Pentegov ${ }^{1}$, Doctor of Technical Science, Professor,

V.M. Sydorets ${ }^{1}$, Doctor of Technical Science, Professor,

S.V. Rymar ${ }^{1}$, Doctor of Technical Science, Senior Research

Scientist,

${ }^{1}$ Paton Electric Welding Institute of National Academy of Sciences of Ukraine,

11, Kazymyr Malevych Str., Kiev, 03680, Ukraine, phone +380 442061388 ,

e-mail: elmag@paton.kiev.ua

How to cite this article:

Krivtsun I.V., Pentegov I.V., Sydorets V.M., Rymar S.V. A technique for experimental data processing at modeling the dispersion of the biological tissue impedance using the Fricke equivalent circuit. Electrical engineering \& electromechanics, 2017, no.5, pp. 27-37. doi: 10.20998/2074-272X.2017.5.04. 